\title{
Pengembangan Media Pembelajaran Bulutangkis Menggunakan Video Based Learning pada Siswa Kelas VIII SMP Negeri 3 Sungailiat
}

Igo Apriangga*, Widati Amalin Ulfah, Muhammad Rizkan Khadavi

Universitas Muhammadiyah Bangka Belitung, Pangkalpinang, Indonesia

*Coresponding Author: igoapriangga@gmail.com

\begin{tabular}{ll}
\hline \hline Article history & Latar belakang masalah penelitian ini yaitu pengetahuan siswa \\
Dikirim: & tentang bulutangkis masih kurang, sehingga siswa sulit \\
09-12-2021 & melakukan teknik bulutangkis, terbatas nya fasilititas seperti raket \\
Direvisi: & dan shuttlecock, kurangnya penggunaan media yang sesuai \\
10-12-2021 & dengan karakteristik siswa SMP Penelitian ini bertujuan untuk \\
& mengetahui proses pengembangan media pembelajaran \\
Diterima: & menggunakan video based learning untuk membantu \\
11-12-2021 & pembelajaran PJOK materi Bulutangkis dan mengetahui \\
Key words: & kelayakan media pembelajaran menggunakan video based \\
\hline Media Pembelajaran; & learning Penelitian ini merupakan penelitian pengembangan R\&D \\
Video Based Learning; & dengan rujukan dari Dick \& Carey, terdiri dari sepuluh tahapan \\
Bulutangkis & Hasil Penelitian menunjukkan Video Based Learning "Layak" \\
& sebagai media pembelajaran. Penelitian dari ahli materi \\
& mendapatkan penilaian persentase 84\% dengan kategori "Sangat \\
& Valid", ahli media mendapatkan penilaian sebesar 83\% dengan \\
& kategori "Sangat Valid" dan penilaian guru mendapatkan \\
& penilaian sebesar 87\% dengan kategori "Sangat Valid".penilaian \\
& dari siswa pada saat uji coba satu-satu mendapatkan penilaian \\
& sebesar 90\% dengan kategori "Sangat Baik", penilaian uji coba \\
& kelompok kecil mendapatkan penilaian 88\% dengan kategori \\
& "Sangat Baik" dan uji coba kelompok besar mendapatkan \\
& penilaian sebesar $86 \%$ dengan kategori "Sangat Baik". \\
\hline \hline
\end{tabular}

\section{PENDAHULUAN}

Pendidikan merupakan suatu keharusan bagi manusia karena pada hakikatnya manusia lahir dalam keadaan tidak berdaya, dan tidak langsung dapat berdiri sendiri, dapat memelihara dirinya sendiri. Manusia pada saat lahir memerlukan bantuan orang tuanya. Karena itu pendidikan merupakan bimbingan orang dewasa sangat diperlukan oleh manusia itu sendiri. Menurut Uyoh Sadulloh (2010: 14) berpendapat, "Pendidikan berfungsi untuk meningkatkan mutu kehidupan manusia, baik sebagai individu, maupun sebagai kelompok dalam kehidupan bermasyarakat." Oleh karena itu pendidikan merupakan hal yang wajib ada dalam perkembangan individu itu sendiri.

Guru Ipendidikan jasmani juga dituntut untuk kreatif dalam mengelola pembelajaran. Mulai dari awal pembelajaran sampai akhir pembelajaran. Ketika memberikan materi bahan ajar guru sangat terbantu dengan adanya media ajar. Media bertujuan untuk memudahkan siswa memahami materi 
sekaligus guru menyampaikan materi ajar kesiswa. Siswa juga lebih mudah untuk menerima dan memahami materi ajar.

Berdasarkan hasil observasi yang dilakukan 29 Juni 2020 di SMP Negeri 3 Sungailiat dalam pembelajaran penjas pada kelas VIII materi bulutangkis. Pembelajaran bulutangkis menggunakan media papan tulis putih (white board) sebagai alat bantu dalam mengajar. Adapun kelebihan dan kekurangan penggunaan papan tulis putih (white board) sebagai perangkat pembelajaran adalah kelebihan : (1) Bermanfaat di ruang manapun tanpa harus ada penyesuaian khusus,(2) Pemakai dapat secara fleksibel membuat perubahan-perubahan sementara penyajian berlangsung, (3) Fasilitas papan tulis atau white board selalu tersedia di ruang-ruang kelas. Kekurangan : (1) Terbatas penggunaannya pada kelompok kecil, (2) Memerlukan keahlian khusus dari penyajinya (apalagi jika memerlukan penjelasan verbal), (3) Pada saat menulis di papan, guru membelakangi siswa, dan jika ini berlangsung lama tentu akan mengganggu suasana dan pengelolaan kelas.

Dengan hal tersebut perlunya adanya pengembangan media pembelajaran karena media yang digunakan dinilai kurang optimal. Hal ini dikarenakan : (1) pengetahuan siswa tentang bulutangkis masih kurang, sehingga siswa suli tmelakukan teknik bulutangkis, (2) fasilitas kurang memadai seperti terbatasnya raket dan shuttlecock dan juga belum adanya lapangan bulutangkis sehingga Kegiatan Belajar Mengajar (KBM) tidak efektif, (3) masih kurangnya penggunaan media yang sesuai dengan karakteristik siswa SMP. Tujuan penelitian ini adalah untuk mengetahui karakterisistik media pembelajaran berbasis video (video based learning) pada siswa kelas VIII SMP Negeri 3 Sungailiat

\section{KAJIAN TEORI}

\section{A. Pengertian Bulutangkis}

Permainan bulutangkis merupakan salah satu cabang olahraga permainan yang sangat popular dan digemari oleh masyarakat. Bulutangkis salah satu cabang olahraga permainan yang menggunakan raket sebagai alat pemukul dan shuttlecock sebagai objek pukul. sedangkan Menurut Herman Subardjah 2010: 325 bulutangkis merupakan permainan yang banyak menggunakan kemampuan fisik dengan gerakan cepat dan pukulan keras yang dilakukan dalam waktu beberapa detik diantara reli-reli panjang. Tujuan permainan ini adalah menjatuhkan shuttlecock melewati net ke daerah bidang permainan lawan untuk mendapatkan poin.

\section{B. Media Pembelajaran}

Kata media merupakan bentuk jamak dari kata medium. Medium dapat didefinisikan sebagai perantara atau pengantar terjadinya komunikasi dari pengirim menuju penerima. Tejo Nurseto (2011: 20) mengartikan kata media sebagai segala bentuk dan saluran yang dipergunakan untuk proses informasi. Media pembelajaran adalah adalah alat yang dapat membantu proses belajar mengajar sehingga makna pesan yang disampaikan menjadi lebih jelas dan tujuan pendidikan atau pembelajaran dapat tercapai dengan efektif dan efisien Teni (2018: 171). 


\section{C.Video Based Learning}

Video-Based Learning adalah metode pembelajaran yang menggunakan video yang telah direkam untuk membantu dalam proses pembelajaran. Dengan menggunakan pendekatan video-based learning kita dapat memberikan stimulus pada tiga bagian penting dalam pembelajaran yaitu emotional, intellectual, psycomotoric. VideoBased Learning adalah salah satu metode pembelajaran yang dirasa cocok untuk generasi digital sekarang ini karena tiga alasan berikut ini: a) Menciptakan lingkungan belajar yang menyenangkan dan membuat semakin motivasi siswa untuk belajar. b) Membuat siswa lebih gampang mempelajari dan memahami sebuah materi belajar. c) Membuat siswa lebih tertarik untuk membuat video pembelajaran sesuai dengan materi yang ingin mereka sajikan. Menurut Munadi dalam ( Purwanti 2015 : 44) Video merupakan media penyampai pesan termasuk media audio visual atau media pandang dengar. Media audio visual dapat dibagi menjadi dua jenis: pertama dilengkapi fungsi peralatan suara dan gambar dalam satu unit, dinamakan media audio visual murni; dan kedua media audio

visual tidak murni. Film bergerak, televisi, dan video termasuk jenis yang pertama, sedangkan slide, opaque, OHP dan peralatan visual lainnya yang diberi suara termasuk jenis yang kedua

Karakter anak usia Sekolah Menengah Pertama (SMP) berada pada tahap Iperkembangan pubertas (10-14 tahun). Menurut Syamsu Yusuf (2004: 26-27) masa usia Sekolah menengah bertepatan dengan masa remaja. Masa remaja merupakan masa yang banyak menarik perhatian karena sifat-sifat khasnya dan perannya yang menentukan dalam kehidupan individu dalam masyarakat orang dewasa.

\section{METODE PENELITIAN}

Pengembangan media pembelajaran berupa Video Based

Learning diadaptasi dari penelitian dan pengembangan Penelitian yang dilakukan oleh peneliti menggunakan rujukan dari Dick \& Carey dalam model The Systematic Design of Instruction. Model yang dikemukakan Dick dan Carey ini menggambarkan proses desain fundamental, bersifat sangat rinci, komprehensif, dan reflektif-evaluatif (Abidin, 2014:53).

Model Dick dan Carey pengembangan ini juga memiliki berbagai macam keunggulan sebagaimana yang dikutip oleh Abidin, (2014:41) yaitu : (1) alur pengembangan model jelas, rinci, dan komprehensif, (2) langkah pengembangan model bersifat reflektif kritis, dan (3) model desain sistem pembelajaran dikembangkan di uji coba dalam situasi pembelajaran yang berjenjang dari tahap terbatas, luas, hingga uji validasi.

Subjek penelitian atau istilah responden inilah yang dinamakan informan, di dalam penelitian ini subjek penelitian nya adalah Siswa kelas VIII A 5 Orang, VIIB 25 Orang dan VIII C 3 Orang sebagai sumber informan yaitu pemberi informasi tentang data yang diinginkan peneliti berkaitan dengan penelitian yang dilaksanakan. Instrument penelitian yang digunakan oleh peneliti berupa wawancara dan angket. Wawancara adalah sebuah dialog yang dilakukan oleh pewawancara untuk memperoleh informasi dari terwawancara. Selain menggunakan lembar wawancara, 
pengumpulan data dalam penelitian ini juga akan menggunakan angket skala likert 5. Angket sebagai instrument pengumpulan data dibuat untuk memperoleh informasi yang relevan dalam tujuan penelitian.

\section{HASIL DAN PEMBAHASAN}

Hasil pengembangan produk awal diperlukan untuk mendapatkan gambaran tentang media pembelajaran yang dikembangkan. Meliputi beberapa tahapan, yaitu analisis kebutuhan dan tujuan pembelajaran, analisis pembelajaran (siswa) dan konteks, merumuskan tujuan performansi atau unjuk kerja, mengembangkan instrument atau alat tes, mengembangkan strategi pembelajaran, mengembangkan dan memilih bahan pembelajaran.

\section{Analisis kebutuhan dan tujuan pembelajaran}

Penelitian pendahuluan dilakukan sebagai dasar pengembangan dan gambaran tentang tindakan yang peneliti laksanakan. Penelitian pendahuluan dilaksanakan pada tanggal 26 Juni 2020. Melalui serangkaian observasi pembelajaran PJOK, wawancara kepada guru. Berdasarkan penelitian pendahuluan ditemukan beberapa permasalahan sebagai berikut.

a. Pengetahuan siswa tentang bulutangkis masih kurang, sehingga siswa sulit melakukan teknik bulutangkis

b. Fasilitas kurang memadai seperti terbatas nya raket dan shutllecock dan juga belum adanya lapangan bulutangkis

c. Masih kurangnya penggunaan media yang sesuai dengan karakteristik siswa SMP

Berdasarkan analisis tersebut, peneliti mengembangkan media pembelajaran Video Based Learning. Media pembelajaran interaktif berbasis computer yang dikembangkan menggunakan video tutorial. Media yang dikembangkan adalah mata pelajaran PJOK pada materi permainan bola kecil bulutangkis.

\section{Analisis Pembelajaran}

Berdasarkan analisis pembelajaran diketahui bahwa isi materi pada kompetensi dasar mendeskripsikan konsep pembelajaran bulutangkis bersifat abstrak. Hal-hal yang menjadi kebutuhan "felt need" para siswa adalah gambaran nyata tentang materi bulutangkis. Media pembelajaran Video Based Learning dapat membantu dalam memberikan gambaran nyata tentang pembelajaran bulutangkis.

\section{Analisis pembelajaran (siswa) dan konteks}

Berdasarkan hasil analisis pembelajaran dan konteks diketahui bahwa pembelajaran Penjas khususnya materi bulutangkis pada kelas VIII SMP Negeri 3 Sungailiat belum menggunakan media yang sesuai dengan karakteristik Siswa SMP, guru Penjas hanya menggunakan papan tulis sebagai alat bantu pembelajaran untuk menjelaskan materi bulutangkis. Keterangan ini didapatkan dari wawancara dengan guru penjas.

\section{Merumuskan Tujuan Performasi atau unjuk kerja}

Tujuan perfomansi dan unjuk kerja dari media pembelajaran ini adalah untuk meningkatkan pengetahuan para siswa tentang materi konsep manajemen. Media pembelajaran bertujuan untuk meningkatkan kemampuan siswa dalam belajar mandiri. Secara umum tujuan dari media yang 
dikembangkan adalah mendeskripsikan konsep pembelajaran bulutangkis. Sesuai kompetensi dasar yang ditentukan dalam kurikulum.

Melalui pengemasan media yang menarik dan mudah digunakan, siswa diharapkan dapat belajar secara efektif. Mampu memberikan pengalaman yang berbeda kepada para siswa pada pembelajaran PJOK materi permainan bola kecil bulutangkis.

\section{Mengembangkan Instrumen atau Alat Tes.}

Instrument yang dikembangkan untuk menilai media pembelajaran adalah angket, angket- angket yang telah diisi oleh responden digunakan sebagai dasar untuk merevisi produk yang dikembangkan. Angket evaluasi kelayakan media yang dimembangkan terdiri dari aspek tampilan dan content. Aspek tampilan meliputi penilaian dari beberapa aspek, yaitu : tampilan dan penyajian, suara, dan pemrograman. Aspek content meliputi penilaian dari beberapa aspek, yaitu pembelajaran, isi materi dan komponen video. Pada tahap uji validasi produk, aspek tampilan dinilai oleh ahli media, sedangkan aspek content dinilai oleh materi. Selanjutnya guru dan siswa menilai dari perpanduan aspek tampilan dan content, yaitu :isi materi, pembelajaran, tampilan dan penyajian, suara,dan pemrograman.

\section{Mengembangkan Strategi Pembelajaran}

Media pembelajaran berbasis computer belum dimanfaatkan secara optimal di SMP Negeri 3 Sungailiat. Computer mampu membantu guru dalam kegiatan belajar mengajar. Cara yang dapat dilakukan dengan menyusun sebuah media pembelajaran atau bahan ajar berbasis multimedia

Melalui multimedia mampu membantu siswa belajar secara efektif. Efektif karena menggabungkan berbagai macam media, yaituteks, gambar, grafik, audio, visual atau audio visual. Objek-objek multimedia tersebut digabungkan secara utuh, terintergrasi, dan disesuaikan dengan tujuan pembelajaran yang akan dicapai.

Media pembelajaran Video Based learning dapat dikreasikan menjadi sebuah media pembelajaran berbasis computer model tutorial yang penuh makna. Model tutorial memiliki keunggulan yaitu siswa mampu belajar mandiri dan fleksibel kapan dan dimanapun berada media pembelajaran tersebut akan digunakan. Tahap awal dalam menyusun media dengan model tutorial adalah dengan pembuatan storyboard. Storyboard media pembelajaran berbasis computer model tutorial digunakan untuk perancangan awal sebuah media yang dikembangkan oleh peneliti.

\section{Mengembangkan dan Memilih Bahan Pembelajaran}

Proses pengembangan materi disesuaikan dengan kompetensi dasar yang telah ditentukan. Selanjutnya dikemas secara sederhana dan di organisasikan dengan tepat. Peneliti memilih materi mendeskripsikan konsep permainan bola kecil bulutangkis dikarenakan dalam pembelajaran materi ini bersifat abstrak dan konseptual. Melalui pengembangan media pembelajaran mengongkretkan materi yang abstrak dan memudahkan siswa mempelajari materi yang bersifat konseptual.

Kelebihan Video Based Learning adalah mampu menampilkan video dengan optimal dalam layar computer, sehingga siswa dapat mengamati 
secara langsung. Materi pembelajaran berupa unit-unit kecil video yang terintegrasi dalam suatu program yang utuh.

\section{Validasi Bahan dan Media Pembelajaran}

Hasil validasi bahan dan media pembelajaran berupa validasi yang dilakukan para ahli yaitu dosen dan pelatih bulutangkis. Validasi produk dilakukan untuk memperoleh penilaian kelayakan produk yang dikembangkan sebelum produk diuji cobakan kepada para siswa. Hasil validasi produk terdiri dari 2 tahapan yaitu validasi oleh para ahli media dan ahli materi. Hasil validasi yang diperoleh dalam penelitian sebagai berikut.

a) Ahli Materi

Data hasil validasi berupa kelayakan materi dilakukan oleh ahli materi. Penilaian di olah kedalam bentuk persentase kevalidan yang ditinjau dari aspek pembelajaran,isi Materi dan komponen video.

Tabel 1. Hasil Validasi ahli Materi

\begin{tabular}{|c|c|c|c|}
\hline No. & Aspek & $\begin{array}{c}\text { Rata-rata } \\
\text { Skor }\end{array}$ & Kriteria \\
\hline 1. & Pembelaiaran & 80 & Valid \\
\hline 2. & Isi materi & 83 & Sangat Valid \\
\hline 3. & Komponen Video & 88 & Sangat Valid \\
\hline Rata-rata kevalidan & & $\mathbf{8 4}$ & \\
\hline Kriteria & & Sangat Valid & \\
\hline
\end{tabular}

Penilaian ahli materi dari aspek pembelajaran, isi materi, dan komponen video memperoleh rata-rata skor sebesar 80\%, 83\%,88\% . Penilaian dari aspek pembelajaran memperoleh kriteria "Valid". Penilaian dari isi materi dan komponen video mendapat kriteria "Sangat Valid". Penilaian total dari ketiga aspek mendapat Rata-rata kevalidan sebesar 84\%, masuk pada kriteria "Sangat Valid". Kriteria ini sudah memenuhi syarat kelayakan dari hasil pengembangan media Video Based Learning

b) Validasi Ahli Media

Data hasil validasi berupa kelayakan media dilakukan oleh ahli media. Penilaian di olah kedalam bentuk persentase kevalidan yang ditinjau dari aspek tampilan dan penyajian, Suara dan Pemrograman.

Tabel 2. IHasil Validasi Ahli Media

\begin{tabular}{|llc|c|}
\hline No. & Aspek & $\begin{array}{c}\text { Rata- } \\
\text { rata Skor }\end{array}$ & Kriteria \\
\hline 1. & $\begin{array}{l}\text { Tampilan dan } \\
\text { penyajian }\end{array}$ & 81 & $\begin{array}{c}\text { Sangat } \\
\text { Valid }\end{array}$ \\
\hline 2. & Suara & 80 & Valid \\
\hline 3. & Pemrograman & 87 & $\begin{array}{c}\text { Sangat } \\
\text { Valid }\end{array}$ \\
\hline $\begin{array}{l}\text { Rata-rata } \\
\text { keralidan }\end{array}$ & & $\mathbf{8 3}$ & \\
\hline Kriteria & & $\begin{array}{c}\text { Sangat } \\
\text { Valil }\end{array}$ & \\
\hline
\end{tabular}

Penilaian ahli Media dari aspek pembelajaran, isi materi, dan komponen video memperoleh rata-rata skor sebesar $81 \%, 80 \%, 87 \%$. Penilaian dari aspek pembelajaran memperoleh kriteria "Sangat Valid". Penilaian dari isi materi memperoleh kriteria "Valid" dan komponen video mendapat kriteria 
"Sangat Valid". Penilaian total dari ketiga aspek mendapat Rata-rata kevalidan sebesar 83\%, masuk pada kriteria "Sangat Valid". Kriteria ini sudah memenuhi syarat kelayakan dari hasil pengembangan media Video Based Learning.

\section{Data Hasil Uji Coba Produk}

Uji coba produk pengembangan media Video Based Learning ini dibagi jadi tiga tahap, yaitu uji coba satu-satu, uji coba kelompok kecil, dan uji coba kelompok besar. Media Video Based Learning yang telah dikembangkan di uji coba dalam pembelajaran PENJAS materi Bulutangkis, kemudian para siswa menilai dan memberikan masukan.

Tabel 3. Hasil Rekapitulasi Uji Coba Produk

\begin{tabular}{|c|c|c|c|c|c|c|c|c|}
\hline No. & Uji coba & Materi & Pembelajaran & $\begin{array}{c}\text { Tampilan } \\
\text { dan } \\
\text { Penyajian }\end{array}$ & Suara & Pemrograman & $\begin{array}{c}\text { Rata- } \\
\text { rata }\end{array}$ & Kriteria \\
\hline 1. & satu-satu & 94 & 97 & 92 & 80 & 86 & $\mathbf{9 0}$ & $\begin{array}{l}\text { Sangat } \\
\text { Baik }\end{array}$ \\
\hline 2. & $\begin{array}{l}\text { kelompok } \\
\text { kecil }\end{array}$ & 88 & 93 & 92 & 84 & 83 & $\mathbf{8 8}$ & $\begin{array}{l}\text { Sangat } \\
\text { Baik }\end{array}$ \\
\hline 3. & $\begin{array}{l}\text { kelompok } \\
\text { besar }\end{array}$ & 91 & 83 & 84 & 89 & 82 & $\mathbf{8 6}$ & $\begin{array}{l}\text { Sangat } \\
\text { Baik }\end{array}$ \\
\hline
\end{tabular}

a. Analisis Data Hasil Uji Coba Dari kelayakan Materi

Hasil uji coba satu-satu, uji coba kelompok kecil, dan uji kelompok Besar berupa skor penilaian, kemudian diolah kedalam bentuk persentase kelayakan.data penilaian pada uji coba satu-satu, kelompok kecil dan kelompok besar ditinjau dari kelayakan aspek materi secara berurutan memperoleh rata-rata $94 \%, 88 \%$ 91\%. Maka aspek materi pada uji coba satu-satu, kelompok kecil dan kelompok besar termasuk pada kriteria "Sangat Baik"

b. Analisis Data Hasil Uji Coba Dari kelayakan Pembelajaran

Hasil uji coba satu-satu, uji coba kelompok kecil, dan uji kelompok Besar berupa skor penilaian, kemudian diolah kedalam bentuk persentase kelayakan. Data penilaian pada uji coba satu-satu, kelompok kecil dan kelompok besar ditinjau dari kelayakan aspek pembelajaram secara berurutan memperoleh rata-rata 97\%, 93\% 83\%. Maka aspek Pembelajaran pada uji coba satu-satu, kelompok kecil dan kelompok besar termasuk pada kriteria "Sangat Baik"

c. Analisis Data Hasil Uji Coba Dari Kelayakan Media

Hasil uji coba satu-satu, uji coba kelompok kecil, dan uji kelompok Besar berupa skor penilaian, kemudian diolah kedalam bentuk persentase kelayakan. Data penilaian pada uji coba satu-satu, kelompok kecil dan kelompok besar ditinjau dari kelayakan aspek tampilan dan penyajian secara berurutan memperoleh rata-rata $92 \%, 92 \%$ 84\%. Maka aspek tampilan dan penyajian pada uji coba satu-satu, kelompok kecil dan kelompok besar termasuk pada kriteria "Sangat Baik"

d. Analisis Data Hasil Uji Coba Dari Aspek Suara

Hasil uji coba satu-satu, uji coba kelompok kecil, dan uji kelompok Besar berupa skor penilaian, kemudian diolah kedalam bentuk persentase 
kelayakan. Data penilaian pada uji coba satu-satu, kelompok kecil dan kelompok besar ditinjau dari kelayakan aspek suara secara berurutan memperoleh rata-rata $80 \%, 84 \%$ 89\%. Maka aspek Suara pada uji coba satusatu, kelompok kecil dan kelompok besar termasuk pada kriteria "Baik" dan "Sangat Baik"

e. Analisis Data Hasil Uji Coba Dari Aspek Pemrograman

Hasil uji coba satu-satu, uji coba kelompok kecil, dan uji kelompok Besar berupa skor penilaian, kemudian diolah kedalam bentuk persentase kelayakan. Data penilaian pada uji coba satu-satu, kelompok kecil dan kelompok besar ditinjau dari kelayakan aspek Pemrograman secara berurutan memperoleh rata-rata $86 \%, 83 \%$ 82\%. Maka aspek Pemrograman pada uji coba satu-satu, kelompok kecil dan kelompok besar termasuk pada kriteria "Sangat Baik"

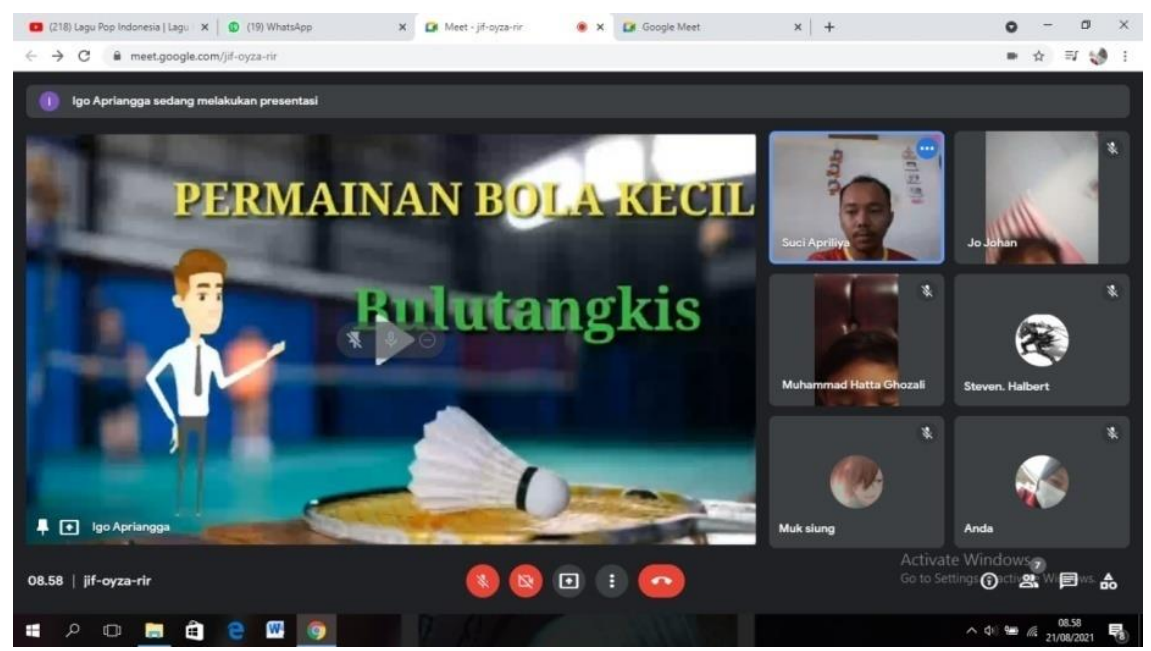

Gambar 1. Pembelajaran Melalui Aplikasi ZOOM pada Uji Kelompok Kecil Sumber : Dokumen Pribadi

\section{KESIMPULAN}

Media pembelajaran yang dikembangkan melalui peneltian ini layak digunakan untuk pembelajaran PJOK SMP Negeri 3 Sungailiat setelah melalui tahap-tahap penelitian. Kelayakan produk media pembelajaran video based learning dalam pembelajaran PJOK kelas VIII tersebut menunjukkan sebagai berikut.

1. Pengembangan Media

a) Ahli Materi

Berdasarkan validasi ahli media terhadap kualitas materi, skor total yang Idiperoleh sebesar $83 \%$ dengan kategori "Sangat Valid". Hasil tersebut menunjukkan bahwa media pembelajaran video based learning baik dan layak digunakan dalam pembelajaran PJOK materi bulutangkis pada siswa kelas VIII SMP Negeri 3 Sungailiat.

b) Ahli Media

Berdasarkan validasi ahli media terhadap kualitas media dari tiga aspek yaitu: 1) Aspek tampilan dan penyajian memperoleh skor total yang diperoleh yaitu $81 \%$ mempunyai kriteria "Sangat Valid". 2) Aspek 
suara memperoleh skor total yaitu $80 \%$ berkriteria "Valid". 3) Aspek Pemograman memperoleh skor total yaitu $87 \%$ berkriteria "sangat valid" . ketiga aspek tersebut memperoleh rata" hasil sebesar $83 \%$ dengan kriteria "sangat valid" .Hasil tersebut menunjukkan bahwa media pembelajaran video based learning baik dan layak digunakan dalam pembelajaran PJOK materi bulutangkis pada siswa kelas VIII SMP Negeri 3 Sungailiat.

2. Karakteristik media

Setiap media pembelajaran mempunyai karakteristik tertentu, baik dilihat dari segi keampuhannya, cara pembuatannya, maupun cara penggunaannya, begitu juga dengan hal nya media pembelajaran video based learning yang memiliki karakteristik sebagai berikut :
a) Terdapat teori bulutangkis didalam video
b) Contoh gerakan teknik bulutangkis ada didalamnya
c) Terdapat animasi yang berbicara
d) Mudah digunakan dalam pembelajaran online atau offline
e) Mudah dioperasikan dalam computer maupun handphone.

\section{Saran}

1. Media pembelajaran Video Based Learning dapat dimanfaatkan sebagai alat bantu dalam proses pembelajaran bulutangkis di kelas (tatap muka) atau secara daring dengan guru atau tanpa guru.

2. Media pembelajaran Video Based Learning juga dapat digunakan dalam penyampaian materi atau dimanfaatkan sebagai referensi guru dalam mengajar, penggunaanya dapat dikombinasikan dengan metode ceramah, diskusi, tanya jawab, dan lain sebagainya.

3. Media pembelajaran Video Based Learning dapat digunakan siswa belajar secara mandiri dirumah, dan juga dapat digunakan untuk mendalami materi sebelum diajarkan oleh guru dikelas dan review materi pembelajaran sesudahnya

\section{DAFTAR PUSTAKA}

AH Sanaky, Hujair. (2010). Media Pembelajaran. Buku Pegangan Wajib Guru Dan Dosen. Yogyakarta: Kaukaba Dipantara

Dick, W., dan Carey, L. (1978). The Systematic Design of Instruction. Boston: Scott, Foresman and Company.

Syamsu Yusuf. (2004). Psikologi Perkembangan Anak \& Remaja. Bandung: PT Remaja Rosdakarya.

Sugiyono. (2015) Metode Penelitian Kuantitatif, Kualitatif dan $R \quad \& \quad D$. Bandung: Alfabeta,

Uyohsadulloh. (2010) Pendagogik (Ilmu Mendidik). Bandung: Alfabeta

Robet, (2013). Pembuatan Materi Belajar Dengan Pendekatan Video Based Learning, Jurnal Time STMIK Medan Vol 2 No 2 : 39-41 
Purwanti Budi, (2015), Pengembangan media Video Pembelajaran Matematika dengan Model Assure, jurnal Kebijakan dan Pengembangan Pendidikan SMK Negeri 2 kota Probolinggo Vol. 3 No. 14247

Subardjah Herman, (2010), Hasil Belajar Keterampilan Bermain Bulutangkis Studi Eksperimen Pada Siswa Diklat Bulutangkis FPOK-UPI, Jurnal Cakrawala Pendidikan ,Universitas Pendidikan Indonesia, Vol. 3 No.1 325-326

Nerseto Tejo (2011), Membuat Media Pembelajaran Yang Menarik, Jurnal Ekonomi dan Pendidikan, Fakultas Universitas Negeri Yogyakarta. Vol. 8 No. 1 20-21 